\title{
Edwardsia callianthus spec. nov. A New British Species from Menai Straits.
}

\author{
By \\ Ruth Rawlinson, M.Sc., \\ Herdman Scholar and Forbes Exhibitioner in the Department of Zoology, \\ Liverpool University.
}

With 11 Figures in the Text.

\section{CONTENTS.}

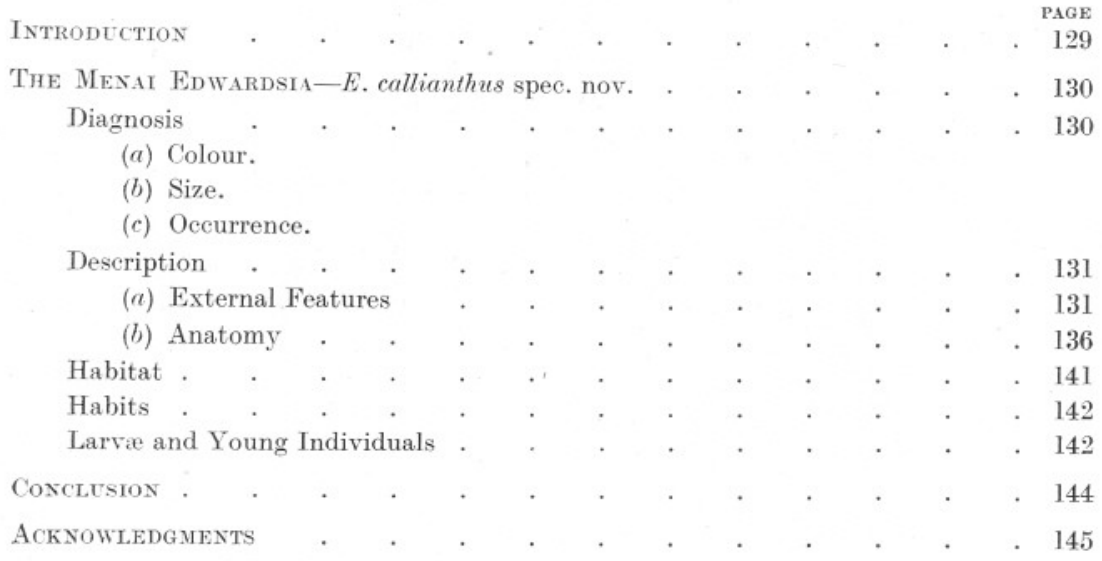

\section{INTRODUCTION.}

While co ecting in Menai Straits in July, 1932, Professor Orton found three spe imens of an Edwardsia-like anemone. They were kept alive in finger bowls for several months; and when they were examined in the following November about two dozen young anemones were discovered with them. These Professor Orton kindly showed to me, and suggested a further examination of the young and adults.

On investigation it was found that the adults possessed all the characters of the genus Edwardsia as defined by Carlgren and Stephenson (1) but that they differed from other known British members of the genus in having more than sixteen tentacles and a scattered arrangement of the nemathybomes, which as well as being scattered are not visible in the living animal, at least under a binocular microscope. 
Several unsuccessful attempts to collect more specimens of this new anemone were made by H. A. Cole, M.Sc., of the University College, Bangor, and myself. In March, 1933, however, we were successful, and since then I have obtained approximately thirty specimens at various times of the year.

\section{THE MENAI EDWARDSIA \\ EDWARDSIA CALLIANTHUS SPEC. NOV.}

\section{Diagnosis.}

Physa well developed, perforated by numerous pores. Scapus with a fairly thick periderm. Nemathybomes not visible in the living anemone, numerous, small, irregularly scattered and usually single. Tentacles sixteen to thirty-three in number. They are arranged in three cycles, an exocœlic and an outer and inner endocœlic cycle. In all the specimens so far examined with twenty or more tentacles there were only four tentacles in the inner endocœlic series, and these belonged, wherever their arrangement was fully ascertained, to the directive endocoles, and to the dorso-lateral primary endocœles. The tentacles were therefore arranged as follows : $4,6,10=20 ; 4,7,11=22 ; 4,8,12=24 ; 4,9,13=$ $26 ; 4,12,16=32$, etc. Pennons of the macrocnemes in the upper part of the fertile region with about twenty-five to thirty folds, some of which are branched, particularly those in the outer part of the pennon. Outer lamella of the mesenteries attached to the pennons some distance from their outer edge. Parietal muscles, in the upper part of the fertile region, triangular in transverse section, with a thick central stem and about seven fairly stout branches on either side, some of which may bifurcate. Lower down the column the parietal muscles are more elongate and their branches not so spreading. Their extension on to the column wall is about as usual. Microcnemes present but small. Unexploded nematocysts of the tentacles $14-29 \times 2-5 \cdot 2 \mu$, those of the scapulus $8-16 \times 2-3 \cdot 5 \mu$ and of the nemathybomes $26-71 \cdot 7 \times 2 \cdot 1-7 \cdot 3 \mu$. Nematocysts of the actinopharynx of two kinds, a small variety, $7-11 \times 1-2 \cdot 5 \mu$ with the basal part of the thread visible in the unexploded capsules and a large variety $17 \cdot 7-36 \cdot 5 \times$ $2-4 \cdot 7 \mu$ with the thread entirely concealed. Tentacle spirocysts $11 \cdot 4-$ $27 \times 2-7 \cdot 3 \mu$. A single ventral siphonoglyph is present.

(a) Colour.

Physa :-

Transparent and colourless.

Scapus-periderm :-

Rusty red or sandy-brown, frequently greyish black towards the oral end. 


\section{Tentacles :-}

Translucent and sometimes colouriess, pale brown or pink. Pattern present or absent, when present it is either a small white fleck at the tip or a fine white continuous or discontinuous line along their length.

Disc :-

Transparent and colourless, grey or brown with a chalky or creamy white powdering developed as alternating broad and narrow triangles opposite the endocœlic and exocœlic tentacles respectively and with their apices directed towards and sometimes extending on to the top of the hypostome where they may then form a white encircling ring just beneath the lip lobes. The mesenterial insertions show as grey or brown radiating lines between the white triangles.

Scapulus :-

Transparent and colourless sometimes with two broken bands of chalky or creamy white, one at the bases of the tentacles and the other about half-way down its length. The former band is often absent, the latter is usually present and frequently developed as a series of deep or shallow inverted U-shaped markings but sometimes as irregular rectangles, one on each scapular ridge. The lip lobes and the actinopharynx are usually dull orange but occasionally pink. The latter shows through the scapulus as a coloured column.

(b) Size.

The length of the column in mature specimens is about $4-6 \mathrm{~cm}$., the breadth, $0 \cdot 3 \mathrm{~cm}$.

\section{(c) Occurrence.}

The species is so far known only from Church Island, Menai Straits. It is found at low water of Spring tides or just below this level, in sandy areas mixed with fine gravel and small stones (see page 141).

\section{DESCRIPTION.}

(a) External Features.

The body is vermiform in extension. It is clearly divisible into a physa, scapus and capitulum.

The physa, when expanded, is a thin-walled bulb with eight longitudinal lines which represent the insertions of the macrocnemes. Sometimes it shows one or two circular constrictions. It may be completely collapsed by the gradual invagination of its central part so that it appears as a flat disc with eight furrows radiating from a central pit. Its surface is covered with microscopic adhesive rugæ. At the aboral end there is a 
terminal pore with several other smaller apertures (9 and 12 in two sectioned specimens) arranged in a circle round it.

The scapus is very contractile. When expanded it is long and slender. It is widest just below the middle and narrows at either end. It is enveloped in a tough leathery periderm which is in close contact with the surface of the body but may be readily peeled off. Masses of minute

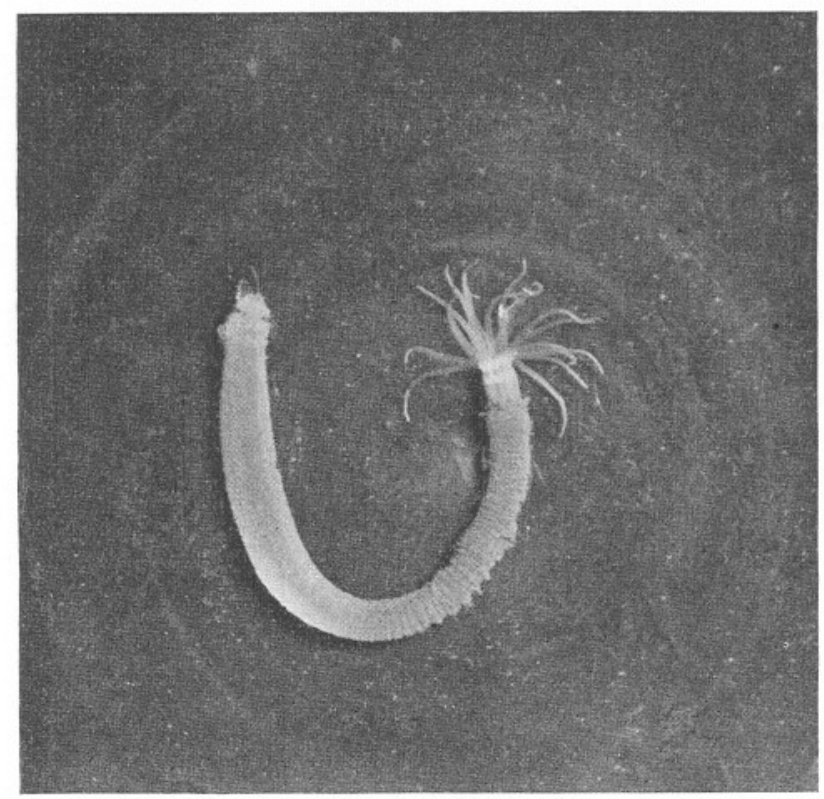

Fig. 1.-Eduardsia callianthus showing the sandy investment. This specimen was semi-nareotised and shows the physa in a collapsed state. $\times$ about $1 \frac{1}{2}$. Photograph by P. Bond.

oval greenish brown bodies, sand grains and a few diatoms adhere to its outer surface and give it a fine transversely furrowed appearance (see Fig. 1). The thickness of the accumulated particles varies in different specimens; where they are plentiful the furrows are quite distinct, where they are less abundant the furrows are hardly perceptible. Overhanging the junction between the scapus and the physa there is often a particular accumulation of sand which forms an irregular frill. The mesenterial insertions are not visible in fully expanded specimens except in those with a very thin investment. In a semi-contracted individual they show as furrows in the anterior half of the scapus while in a fully contracted animal the furrows may appear along its entire length.

The distal portion of the column, as in other Edwardsias, consists of two 
regions which are anatomically distinct from one another, the capitulum proper, a narrow zone just beneath the tentacles, and the scapulus, a more extensive region between the capitulum and the scapus, and belonging morphologically to the latter.

The capitulum is externally indistinguishable from the scapulus and

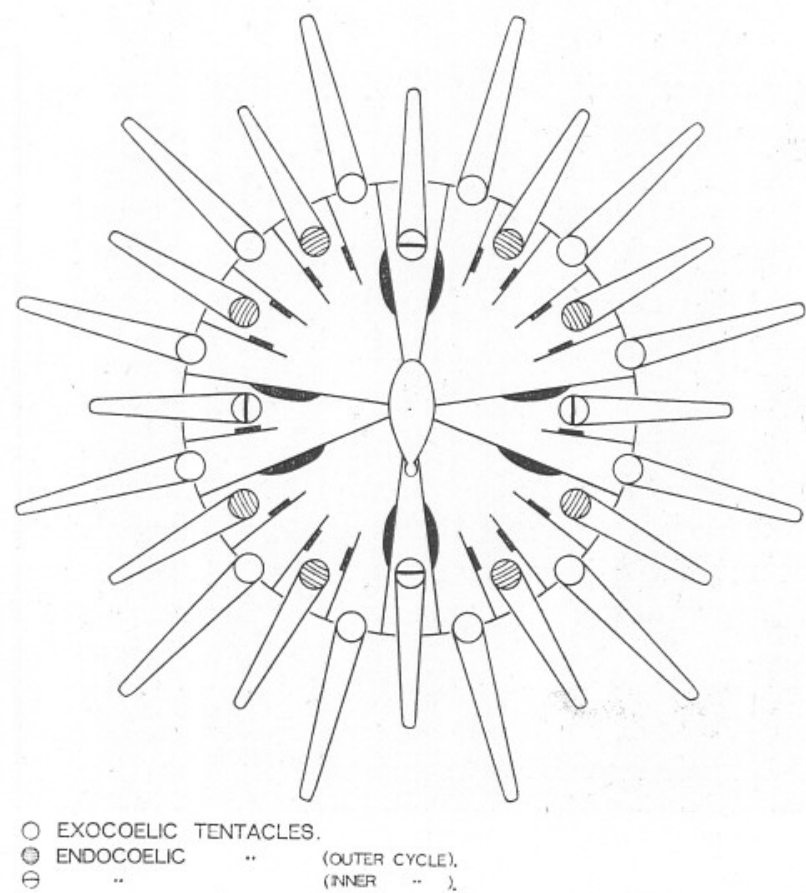

FIG. 2.-Diagram showing the arrangement of the tentacles in a specimen of $E$. callianthus in which their number was twentyfour. (The microcnemes do not have retractor muscles, they are figured in the diagram to show how the mesenteries pair.)

bears from sixteen to thirty-three tentacles. In thirty-one specimens their numbers were as follows :-

$\begin{array}{lrrrrrrrr}\text { No. of tentacles } & 16 & 17 & 20 & 22 & 23 & 24 & 26 & 33 \\ \text { No. of individuals } & 2 & 3 & 8 & 7 & 1 & 6 & 2 & 2\end{array}$

The anemones with sixteen tentacles were doubtless young ones, they were smaller than the rest. The tentacles are arranged in three distinct cycles; there is an outer exocœlic series, the members of which alternate with the tentacles of an inner endocœlic series in which two cycles, an inner and an outer, are distinguishable (see Fig. 2). In a fully expanded anemone the exocœlic tentacles are usually longer than the endocœlic. It is nevertheless often impossible to see any difference between 


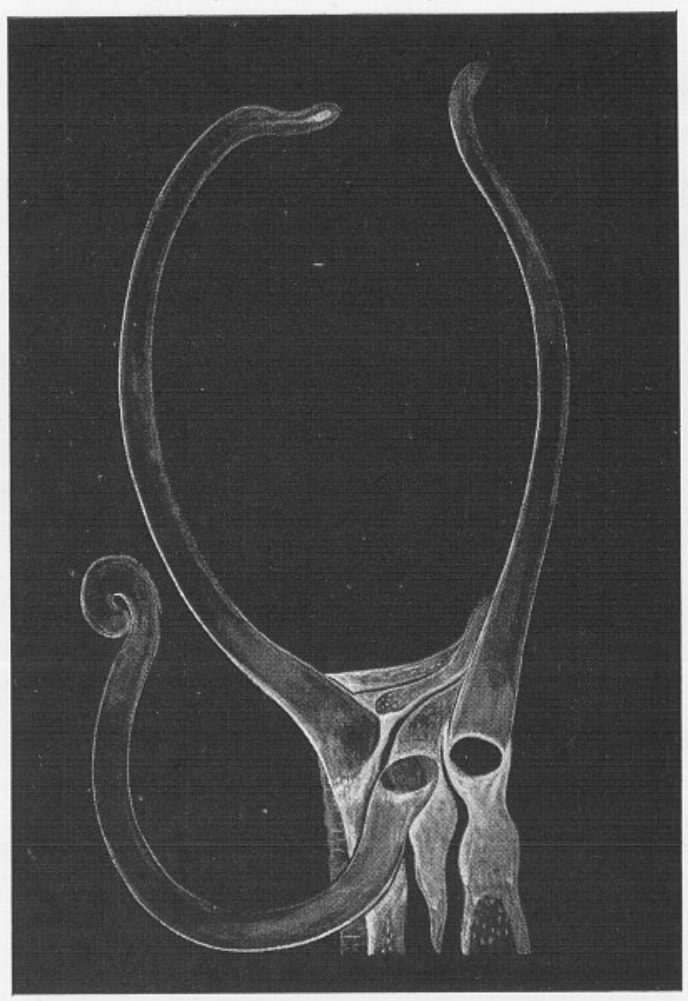

Fig. 3.-A side view of the disc and upper part of the scapulus of $E$. callianthus to show the pattern.

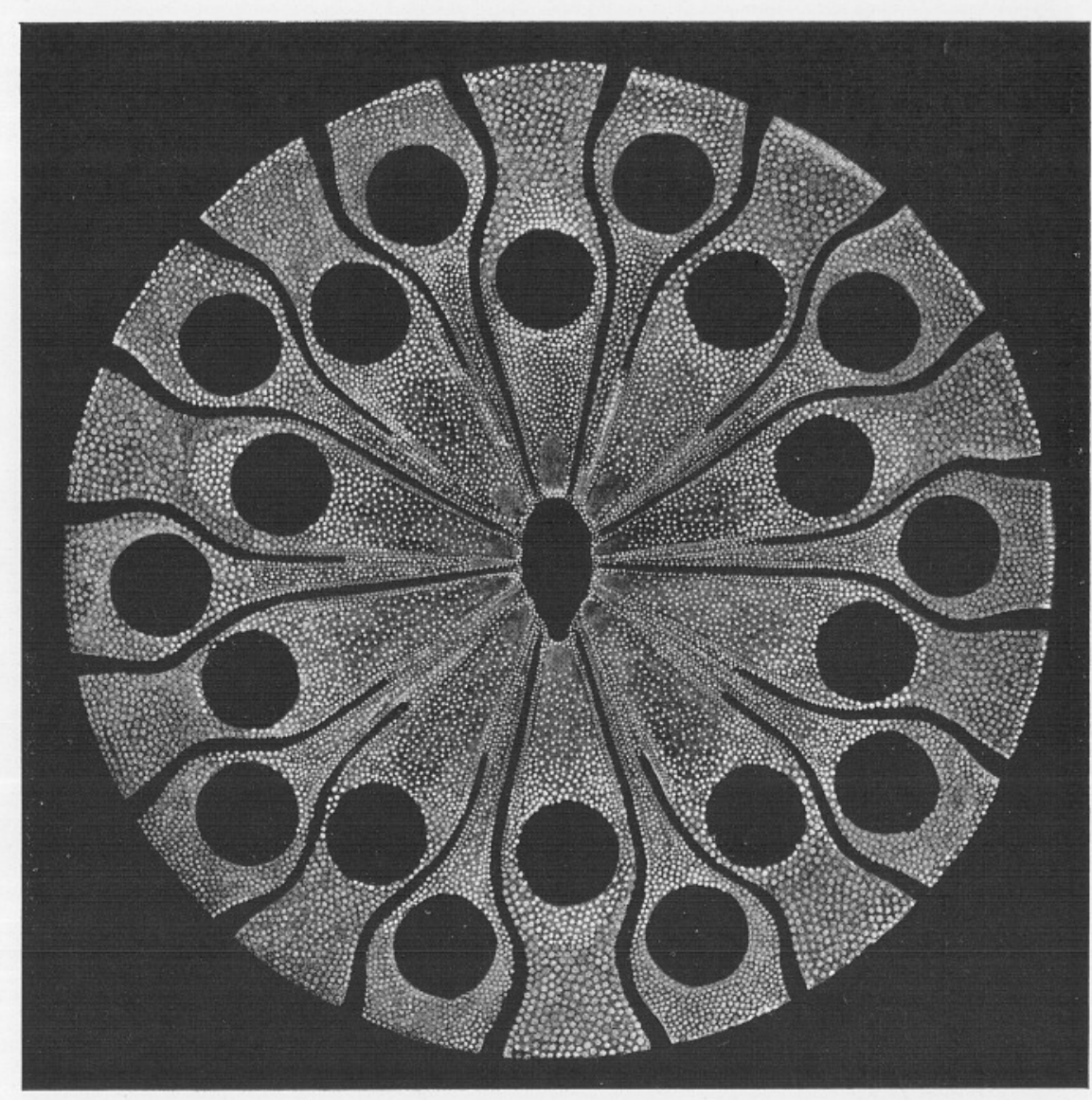

Fig. 4.-Diagram of the pattern on the dise and on the upper part of the scapulus just beneath the tentacle bases of $E$. callianthus. (The tentacles are not drawn.) 
their relative lengths and sometimes the exocœlic ones appear shorter, particularly in a partially expanded individual. The inner tentacles are frequently held in a vertical position with their tips bent inwards while the exocœlic ones are turned back to lie either flat on the substratum or against the scapulus. They are all very contractile, and continually in motion. They are long, slender and tapered towards the distal extremity, where they terminate bluntly. The endocœlic tentacles are however somewhat thicker than the exocœlic ones. They are all usually the same colour, either transparent and colourless, pale brown, pale or deep pink, but in one individual the exocœlic series was brown and the endocœlic series pink. In a few anemones there was no colour pattern, in others some or all the tentacles showed a small white fleck at the tip (see Fig. 3), while others had a fine white continuous or discontinuous line along their length. Any or all of these markings may be present in the one individual.

The arrangement of the tentacles seems to follow a fairly definite plan. Seven living and several preserved specimens which I have examined in detail each possessed more than twenty tentacles, four of which belonged to the inner cycle of the endocœlic series; they were the dorsal and ventral directive tentacles, and a tentacle in each dorso-lateral primary endocœle. Figure 2 shows the usual arrangement of the tentacles when their number is twenty-four. Two anemones, each with twenty-two tentacles, showed a similar arrangement except that in one of the dorso-lateral macrocœles there was only one endocœlic and two exocœlic tentacles. In Figure 4, representing a specimen with twenty tentacles, the same arrangement is also evident but in both the dorso-lateral macrocœles there is only one endocœlic and two exocœlic tentacles. Professor Stephenson (2) has figured the tentacle plan of a specimen with thirty-three tentacles which was sent to him. Here, also, the inner cycle of the endocœlic series contains four tentacles which are situated in the same positions as in the specimens which I have examined.

The hypostome forms a prominent cone with eight distinct protrusible lip lobes surrounding a slightly elongated mouth.

The disc pattern as illustrated in Figure 4 is typical of all the specimens which have been examined, irrespective of their tentacle number. Minor variations from this diagrammatic representation do, however, occur. The intensity and extent of the pattern varies in different individuals. In some the whole disc is white except for the grey or brown lines which mark the insertions of the macrocnemes and microcnemes, in others the pattern is not so extensive, being developed only at the foot of each tentacle and as a narrow streak along the insertion of each mesentery. It becomes very feint when the animals are kept in captivity. The white encircling ring beneath the lip lobes may be present or absent. 
The scapulus is a short region about $5 \mathrm{~mm}$. long. The interseptal areas appear as eight broad ridges which are separated from one another by the insertions of the macrocnemes. When slightly contracted it shows a series of very fine white transverse lines. Figure 3 shows the pattern at the tentacle bases developed as alternating triangles and inverted U-shaped markings, and Figure 1 the band of inverted U-shaped markings mid-way between the bases of the tentacles and the scapus. The tentacles may be completely withdrawn by the gradual invagination of the capitulum and the scapulus into the scapus. The anterior end of the scapus with its investment is also frequently invaginated but sometimes the investment projects as a short free tube.

\section{(b) Anatomy.}

The material for anatomical study was narcotised with menthol, fixed in Bouin's fluid, stained in bulk with borax-carmine and embedded by the usual xylol-wax method. The sections were counter-stained with picroindigo-carmine. A detailed account of the anatomy is inessential, since in general it is similar to that of other species of Edwardsia.

The ectoderm of the physa is columnar and contains numerous gland cells. They secrete an adhesive mucus which attaches the anemone to the substratum. The structure of all the apertures of the physa is the same. Each is developed as a gap in the body wall and is surrounded by circular muscles. Projecting through each aperture there is an epithelial plug which is pierced by a canal. Sometimes the plug is inwardly directed towards the cœlenteron, at other times outwardly directed. Carlgren (3) has described similar epithelial plugs in the physa of $E$. vitrea and $E$. vega. He suggests that in the former they function as movable stoppers and that the observed difference in their position depends upon the state of contraction of the physa. This same explanation is probably also true for $E$. callianthus. The possibility of a change in the position of the plug makes it impossible to say whether the apertures are developed as ectodermal invaginations or $\varepsilon \mathbf{s}$ endodermal evaginations.

The scapus has a well-developed periderm. The mesoglœa is thick and laminated, and contains a large number of nemathybomes. They are not visible in the living animal even when the investment is removed, because they are sunk into the mesoglœa and not mounted on prominent tubercles as in certain other species of Edwardsia. Their distribution may be seen if a portion of the wall is removed, cleared and mounted in glycerine (see Fig. 5). They are absent from all other parts of the body, although a few may occur in the transitional region between the scapus and the physa. Their structure is as usual. Each is a spherical cavity which opens on to the ectoderm by a narrow aperture. The capsules of the nemathybome nematocysts have a wide range in size (see Table I). Their 
shape is also variable; some are bow-shaped, others straight, but all degrees of curvature are met with between these two extremes. They are all slightly broader at one end. It is possible that the variation in shape depends upon their position in the nemathybomes, the curved ones lying against the walls of the cavity, the straight ones in the middle ; but both directed towards the aperture in such a position that they can be exploded.

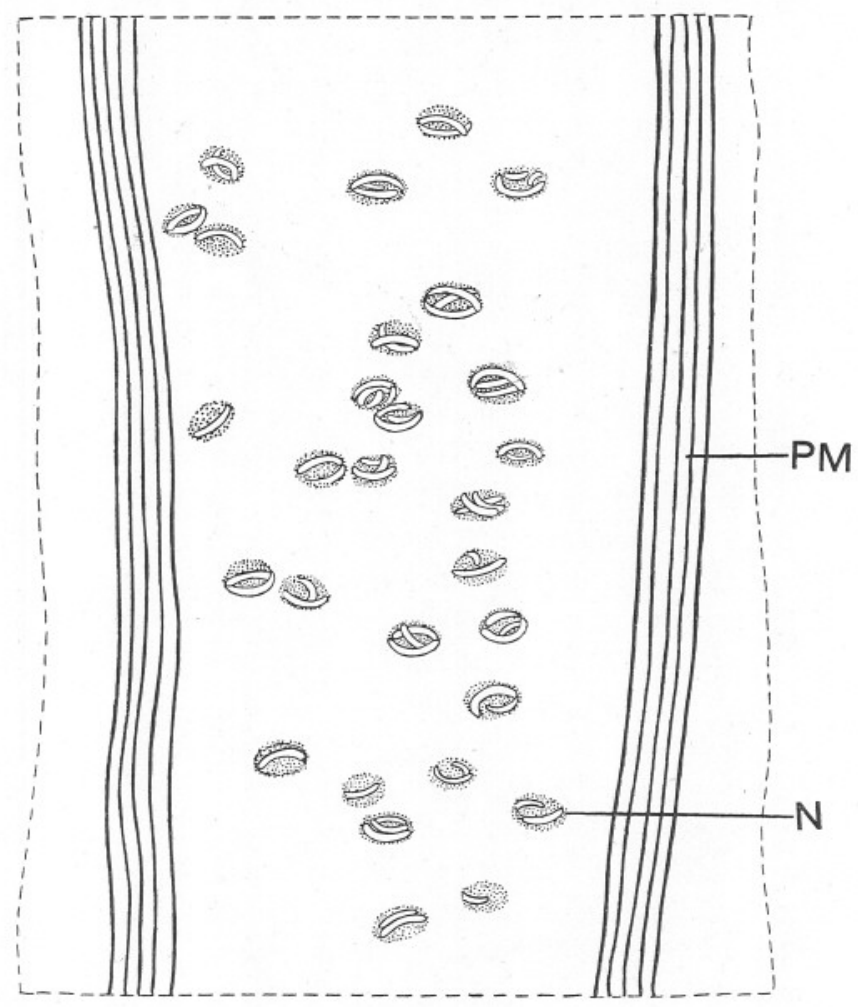

Fig. 5.- Surface view of a portion of the scapus wall cleared in glycerine to show the arrangement of the nemathybomes. N. nemathybome, P.M. parietal muscle. $\times 80$.

The anatomy of the scapulus, capitulum and tentacles agrees with that of other species of Edwardsia (3). The actinopharynx is about the same length as the scapulus. It is lined with ciliated epithelium which is raised into eight broad folds, one opposite the attachment of each macrocneme. Between each pair of folds there is a deep furrow except between the folds corresponding to the dorsal directives, which are only indistinctly separated from one another. A transverse section through the actinopharynx is very similar to that of $E$. callimorpha (Fig. 15, 4). The ventral siphonoglyph is structurally scarcely distinguishable from the remaining 


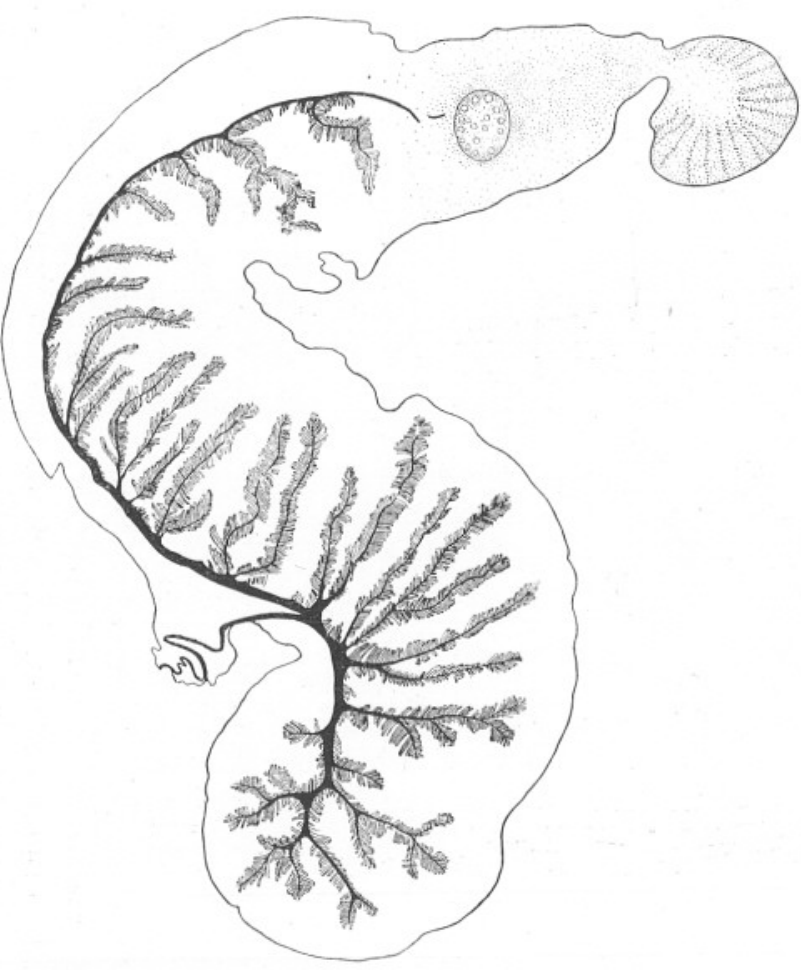

Fig. 6.-A transverse section of a retractor muscle in the upper part of the fertile region of $E$. callianthus. (The mesoglœa is shown as black and the fertile and cnidoglandular areas are stippled.) $\times 186$.

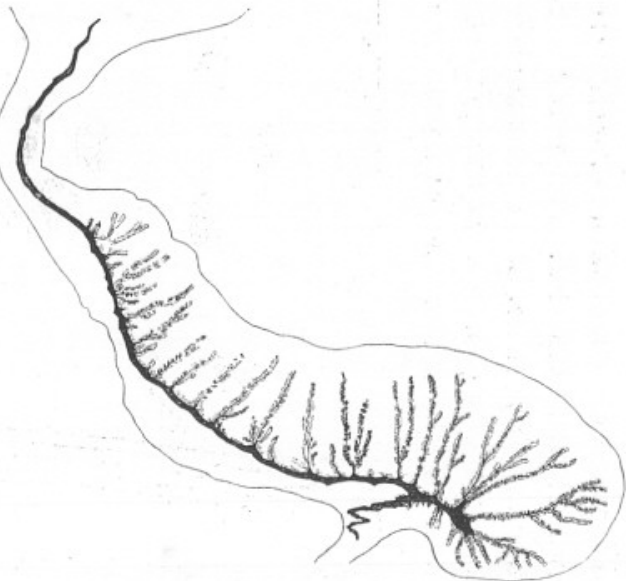

Fig. 7.-A transverse section through a retractor muscle in the region of the actinopharynx of E. callianthus. (The mesoglœa is shown as black.) $\times 189$. 
furrows. Small nematocysts are present in the epithelium of the actinopharynx and the ectoderm of the scapulus, and along with the spirocysts they are very abundant in the tentacles. A comparison of their sizes is given in Table $\mathrm{I}$.

TABLE I.

\section{A Comparison of the Size of the Nematocysts from Various REgions of the Ectoderm of E. callianthus.}

(The individuals which were used were $4-6 \mathrm{~cm}$. long. The measurements were made of living capsules unexploded, unstained and mounted in sea-water unless otherwise stated. The width measurements were made half-way down the capsules.)

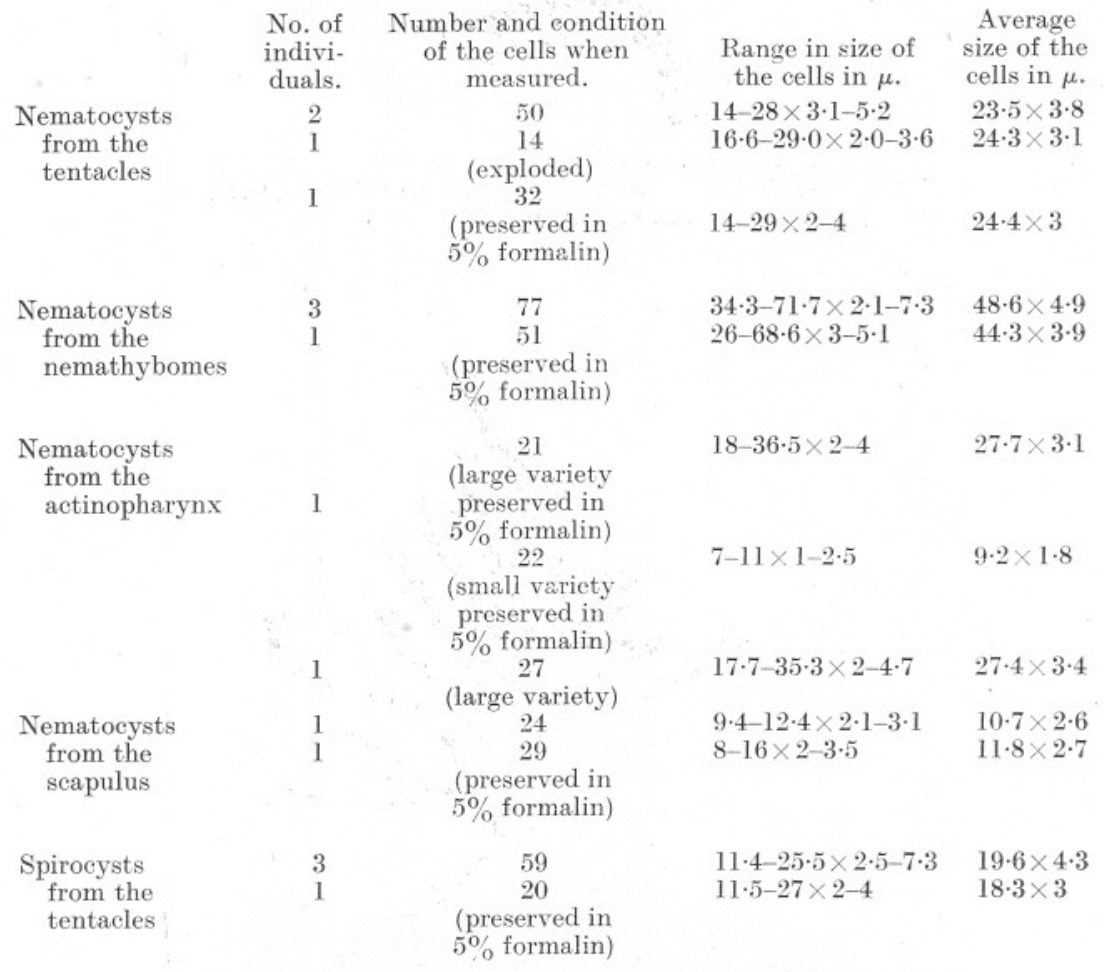

There are eight typical Edwardsian mesenteries extending throughout the entire length of the column, and a series of microcnemes which are confined to the capitular region. The latter, as usual, are small lamellæ each with a mesoglœal core and without either retractor muscles or mesenterial filaments. Figure 2 shows four microcnemes pairing with the lateral macrocnemes, and an additional pair corresponding with each endocœlic tentacle.

The structure of the perfect mesenteries is typical. The form of the 


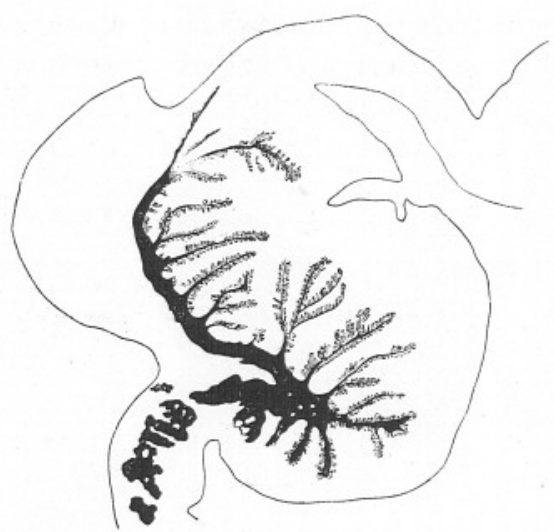

FIG. 8.-A transverse section of a retractor muscle below the fertile region of $E$. callianthus. (The mesoglœa is shown as black.) $\times 186$.

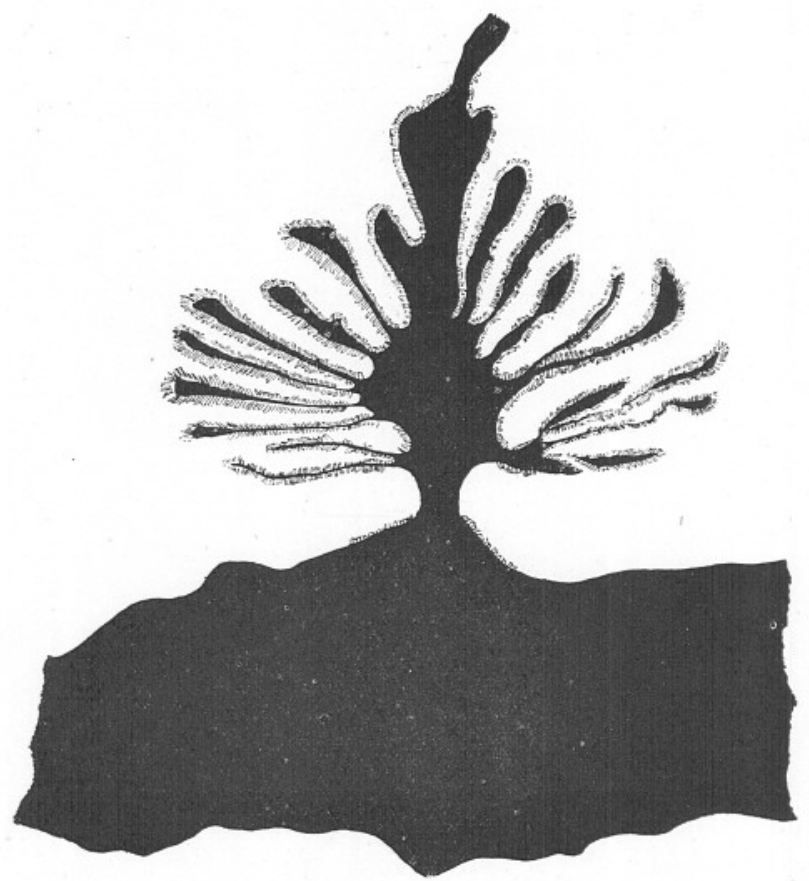

Fig. 9.-A transverse section of a parietal muscle in the upper part of the fertile region of E. callianthus. (The mesoglœa is shown as black.) $\times 672$. 
pennons and their retractor muscles as seen in transverse section gradually changes from the oral to the aboral end of the animal. In the upper part of the fertile region and in all parts anterior to it, the retractor muscles have about twenty-five to thirty folds, some of which branch two or three times (see Figs. 6 and 7). In the reproductive region the muscle processes are better developed than elsewhere and give the retractor a distinctly feathery appearance. Below the reproductive tract, the folds gradually decrease in number and the mesoglœal core thickens (see Fig. 8). Figure 9 represents a parietal muscle from the upper part of the fertile region. Although the form of the retractor and parietal muscles is a useful character for the identification of species belonging to the genus Edwardsia, Carlgren (3) has shown that their form varies in individuals of the same species from different localities. The ciliated tracts are discontinuous. Below the fertile region the inner part of each mesentery is drawn out into a thin lamella as in the species described by Faurot as $E$. beautempsii (Plate I, Fig. 3, 5).

\section{HABITAT.}

The shore off Church Island, Menai Straits, is rocky with large stretches of fine mud and sand. In certain small areas, the sand just beneath the surface is a distinct rusty-red-brown in colour and is mixed with gravel and small stones. It was in sheltered ground of this type that most of the anemones were discovered. They may be found at low water of

\section{TABLE II.}

\section{Analysis of the SAND InHabited BY E. callianthus AT Church Island.}

Size of mesh through which the particles were passed and on which they were collected. On $15 \mathrm{~mm}$. Through.

$15 \mathrm{~mm}$. on $5 \mathrm{~mm}$.

$5 \mathrm{~mm}$. on $4 \mathrm{~mm}$.

$4 \mathrm{~mm}$. on $3 \mathrm{~mm}$.

$3 \mathrm{~mm}$. on $2 \mathrm{~mm}$.

$2 \mathrm{~mm}$. on $1 \mathrm{~mm}$.

$1 \mathrm{~mm}$. on $0.5 \mathrm{~mm}$.

$0.5 \mathrm{~mm}$. on $0.25-0.35 \mathrm{~mm}$.

$0 \cdot 25-0 \cdot 35 \mathrm{~mm}$. on $0 \cdot 07-0 \cdot 1 \mathrm{~mm}$.

$0.07-0.1 \mathrm{~mm}$. on filter paper

\begin{tabular}{|c|c|c|c|}
\hline $\begin{array}{c}\text { Sample } 1 \\
\% \text { dry weight. } \\
0\end{array}$ & $\begin{array}{c}\text { Sample } 2 \\
\% \text { dry weight. } \\
0\end{array}$ & $\begin{array}{c}\text { Sample } 3 \\
\% \text { dry weight. } \\
5 \cdot 94\end{array}$ & $\begin{array}{l}\text { Designation. } \\
\text { Stones. }\end{array}$ \\
\hline $4 \cdot 83$ & 3.98 & $5 \cdot 0$ & Coarse gravel \\
\hline $2 \cdot 90$ & $1 \cdot 85$ & $2 \cdot 467$ & \\
\hline $2 \cdot 60$ & $2 \cdot 06$ & $1.95\}$ & and Fine \\
\hline $2 \cdot 93$ & $2 \cdot 21$ & $2 \cdot 43$ & \\
\hline $7 \cdot 59$ & $5 \cdot 24$ & $6 \cdot 31$ & Coarse sand. \\
\hline $9 \cdot 83$ & $12 \cdot 75$ & $8 \cdot 42$ & Medium , \\
\hline $26 \cdot 11$ & $16 \cdot 67$ & $20 \cdot 097$ & Fine sand \\
\hline $\begin{array}{l}33 \cdot 61 \\
10 \cdot 10\end{array}$ & $40 \cdot 62$ & $\begin{array}{l}34 \cdot 63 \\
1.7 \cdot\end{array}$ & and silt. \\
\hline & $14 \cdot 59$ & $12 \cdot 72$ & \\
\hline
\end{tabular}

Spring tides, but the majority live in regions unexposed by the average tides. The analysis of three separate samples of sand in which the anemones were living is given in Table II. The sand was passed through a series of zinc sieves with circular perforations ranging from $15 \mathrm{~mm}$. in $\frac{1}{2}-\mathrm{mm}$. sizes down to $0.5 \mathrm{~mm}$. The residue collected on the $0.5-\mathrm{mm}$. sieve 
was then passed through a silk mesh of $0 \cdot 25-0 \cdot 35 \mathrm{~mm}$. and collected on a silk mesh of $0.1 \mathrm{~mm}$. The sand and silt which passed through the $0 \cdot 1-\mathrm{mm}$. mesh was collected on weighed filter papers. The graded samples thus obtained were dried in the sun, weighed, and their percentage of the total sample determined. Following Allen's nomenclature (6) the habitat of $E$. callianthus may be defined as mainly fine sand with a small proportion of medium and course sand and gravel.

\section{HABITS.}

$E$. callianthus lives in narrow burrows a few inches below the surface of the sand. It appears to be gregarious; sometimes two individuals inhabit the same burrow. On one occasion twenty specimens were collected from three forkfuls of sand and on another occasion seven from one forkful, yet none were discovered in the immediate neighbourhood. The individuals are usually free, but the physa may be attached to a pebble.

The anemones live quite well when kept in the laboratory in finger bowls containing a fairly thick layer of sand. They frequently adhere firmly to the bottom of the vessel by means of the physa. Sometimes they burrow in the sand, at other times they are free on the surface. The physa is usually regarded as the burrowing organ of the Edwardsias, but I have seen one specimen of $E$. callianthus burrowing with its tentacles. It was lying fully expanded on the sand and commenced to burrow slowly forwards with its tentacles extended and actively moving. They seemed to be the principal agents in moving the sand. One anemone was found in its natural habitat lying free on the sand beneath the water. It was perfectly healthy and lived in the laboratory for some time afterwards.

On several occasions complete narrow rings of investment were discovered in the bowls in which the anemones were living. They were probably cast off from the aboral end of the animal when the physa contracted, since the covering is always more irregular here than elsewhere.

During the first few weeks of captivity the anemones quickly contract at the least vibration; later they are much less sensitive and remain expanded for long periods. A similar habit is recorded for E. callimorpha (under the name claparedii, $\mathbf{y}$ ).

\section{LARV a AND Young Individuals.}

Relatively little is known about the early larval stages of the Edwardsidæ, and the records which are available are in many cases very brief. Owing to an insufficient supply of material it has only been possible to make a few observations on the young of $E$. callianthus, but they are of interest for comparison with other members of the family. 


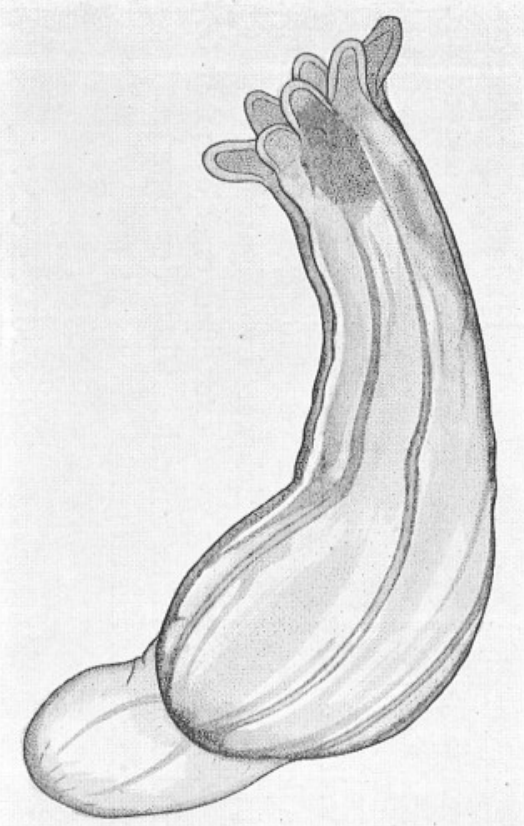

FIG. 10.-E. callianthus, a few days old. (Length of column 1.6 mm.)

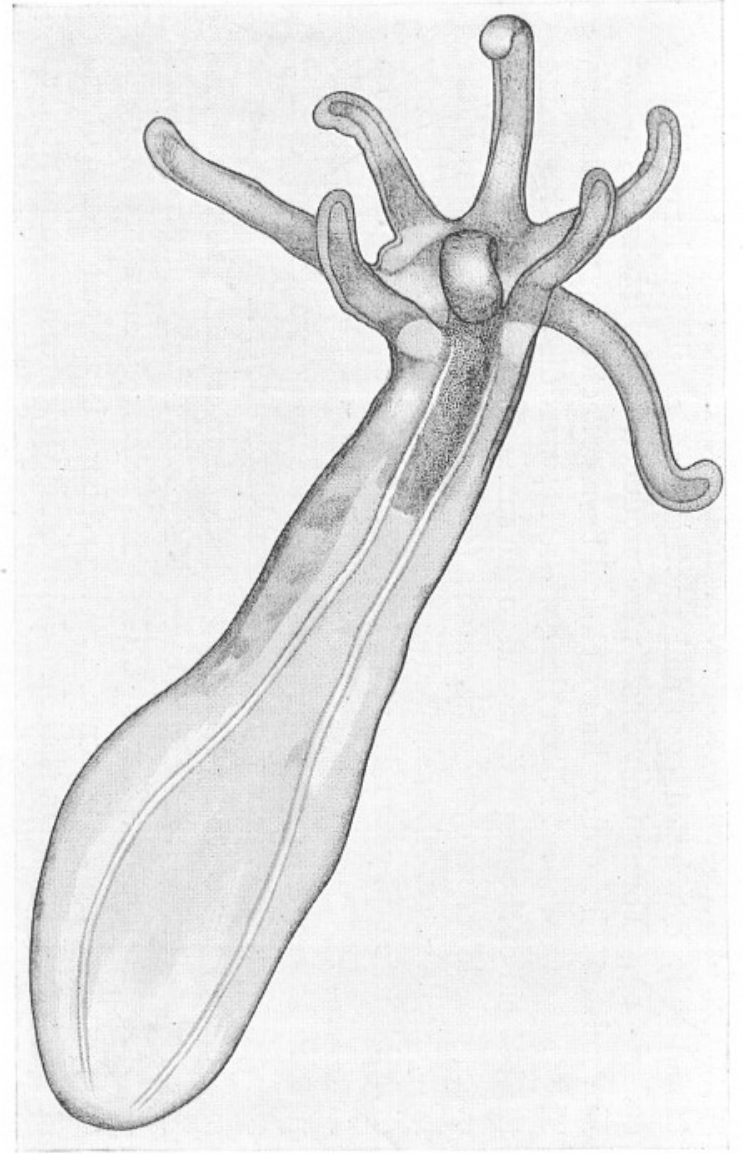



Fia. 11.-E. callianthus eleven days older than the specimen in Fig. 10. (Length of column $1.9 \mathrm{~mm}$.) 
E. callianthus is sexually mature about November and December. Two specimens examined in December, one in 1932 and the other in 1933, contained fully developed eggs and another had a ciliated larva in the cœlenteron. Young individuals were produced in the laboratory about November 17th from adults which had been collected the previous July. The young were about $1.5 \mathrm{~mm}$. long when they were discovered attached to the bottom of the finger bowl and to the surface of the adult. It is however possible that they were liberated a few days earlier. Some were in the late planula stage, others showed eight rudimentary tentacles and the body divisible into a physa and scapus, but there was no sandy investment (see Fig. 10). The physa was colourless and transparent, the scapus pale pinkish brown with the insertions of the macrocnemes showing clearly along its length. There were three tentacles on either side of the mouth and one at either end which was a little shorter than the rest. The hypostome formed a prominent cone. The discovery of young individuals - at the most only a few days old - in a relatively advanced stage of development and the presence of a ciliated larva in the cœlenteron of one adult strongly suggests that $E$. callianthus is viviparous. Viviparity has not so far been recorded in any other species of Edwardsia, although it is suspected in Mitne-Edwardsia carnea. As growth proceeds the tentacles elongate and two fairly distinct cycles of four long ones alternating with four short ones are frequently distinguishable (see Fig. 11).

The anatomical features of the young are similar to those described for other members of the genus $(\mathbf{8}, \mathbf{9}$ and $\mathbf{1 0})$. The youngest larvæ which were sectioned were in the late planula stage, the oldest, with eight rudimentary tentacles. In the former the blastocœle was almost filled with cells in which eight macrocnemes were recognisable. Each mesentery had a thin core of mesoglœa and showed developing retractor muscles. The intermesenterial spaces arise by the gradual disappearance of some of the central cells, those which remain form the endoderm of the scapus wall and mesenteries. The ventro-lateral mesenteries are the largest, and the first to develop mesenterial filaments. The ectoderm of the entire body wall and the epithelium of the actinopharynx is glandular. It contains a large number of clear vesicles. Nemathybomes were not developed in any of the larvæ which were investigated.

When the young were examined on November 30th, one showed a rudimentary ninth tentacle. Their development has not been followed further than this stage.

\section{CONCLUSION.}

One cannot conclude an account of $E$. callianthus without referring to its close resemblance to the anemone described by Dixon (11) as E. timida. 
The external features and the colouring of these two anemones are remarkably similar. Carlgren (1) has recently investigated the anatomy of some specimens of "E. timida" sent to him by Dixon, and as a result of his researches has renamed it Milne-Edwardsia dixonii. A comparison of its anatomical features with those here described for $E$. callianthus shows that these two anemones are quite distinct; nemathybomes, for instance, are absent from $M$. dixonii, whereas they are present in E. callianthus. The close resemblance between their external features has nevertheless led Professor Carlgren to suggest (letter to the author) that Dixon possibly confused two species, the one a real Edwardsia and the other a MilneEdwardsia. Professor Stephenson (2, p. 403) has followed up this suggestion, and finds that not only does Dixon's description probably cover two species, but possibly three. Only one of these (M. dixonii) has been anatomically described; and it is impossible to be certain about the others without obtaining material from Dixon's original locality. In any case, Dixon's use of the name E. timida was unjustified, so that whether or no $E$. callianthus was one of the forms included in his description, it requires a new name and is here characterised as $E$. callianthus spec. nov.

\section{Acknowledgements.}

I have very much pleasure in thanking Professor Orton for his help and for the original specimens of $E$. callianthus, Professor Stephenson for his continued interest and invaluable criticism so kindly given, and also H. A. Cole, M.Sc., for assistance in collecting specimens.

\section{REFERENCES.}

1. Carlgren, O., and Stephenson, T. A. The British Edwardsiidæ. Journ. Mar. Biol. Ass., N.S., Vol. XV, No. 1, 1928.

2. Stephenson, T. A. The British Sea Anemones, Vol. II, London, 1934.

3. Carlgren, O. The Danish Ingolf Expedition. Vol. V, 9, Actinaria, Part 1, Copenhagen, 1921.

4. Stephenson, T. A. The British Sea Anemones, Vol. 1, London, 1928.

5. Faurot, L. Études sur l'anatomie, l'histologie et le développement des Actinies. Archiv. de Zool. Exp. et Gén., 3me Sér., Tome 111, Paris, 1895 .

6. Allen, E. J. On the Fauna and Bottom Deposits near the Thirty Fathom Line from the Eddystone Grounds to Start Point. Journ. Mar. Biol. Ass., N.S., Vol. V, 1897. 
7. Walton, C. L., and Rees, O. M. Some Rare and Interesting Sea Anemones from Plymouth. Journ. Mar. Biol. Ass., N.S., Vol. X, No. 1, 1913.

8. Marks, E. L. Selections from Embryological Monographs. Mem. Mus. Comp. Zool., Vol. IX, No. 3, Harvard, 1884.

9. McMurrich, J. P. Contributions on the Morphology of the Actinozoa. Journ. of Morphology, No. V, Boston, 1891.

10. Wietrzykowski, M. W. Récherches sur le développement de l'Edwardsia beautempsii. Bull. Int. Acad. Sci. Biologische Wissenshaften, No. 7 B, Cracovie, 1914.

11. Dixon, G. Y. Notes on two Irish specimens of Edwardsia timida (Quatrefages). Sci. Proc. Roy. Soc., Vol. V, Dublin, 1886. 